\title{
Pemaksimalan Media Pembelajaran Untuk Pembelajaran Daring Pada SDN 9 Dauh Puri Denpasar Bali
}

\author{
Luh Made Yulyantari $^{1 *}$, Ni Kadek Sumiari ${ }^{1}$, Ni Luh Nyoman Mirah Wedasari ${ }^{1}$ \\ ${ }^{1}$ Institut Teknologi dan Bisnis STIKOM Bali \\ Jl. Raya Puputan No.86, Dangin Puri Klod, Kec. Denpasar Tim., Kota Denpasar, Bali 80234 \\ *E-mail : yulyantari@stikom-bali.ac.id
}

\begin{abstract}
Naskah diterima 20 Juli 2021, Revisi 27 Agustus 2021, Terbit 29 Oktober 2021
Abstrak

Dunia Pendidikan mengalami perubahan yang besar pada Tahun 2020 dikarenakan adanya pandemi Covid-19. Dampak yang paling terlihat atas perubahan dunia pendidikan di tengah pandemi Covid-19 adalah keefektifan proses belajar-mengajar yang berubah menjadi daring. Salah satu SD yang mengalami perubahan tersebut adalah SDN 9 Dauh Puri, Denpasar Utara. Pembelajaran daring yang dilaksanakan saat ini di SDN 9 Dauh Puri menggunakan media WhatsApp dan Google Classroom, akan tetapi dalam pelaksanaannya para guru masih menggunakan akun pribadi dalam penggunaan media pembelajaran daring, sehingga fitur-fitur media pembelajaran tersebut belum dapat dimanfaatkan secara maksimal. Selain itu para guru juga belum memahami secara maksimal dalam penggunaan media pembelajaran tersebut. Berdasarkan permasalahan tersebut, maka melalui kegiatan pengabdian ini dilakukan pendampingan dalam pembuatan akun dengan domain gratis yang disediakan pemerintah (.sch) sekaligus website sekolah. Kegiatan lainnya berupa pelatihan penggunaan Google Form sebagai media pengumpulan tugas dan evaluasi pembelajaran. Metode pelaksanaan dari kegiatan pengabdian terdiri dari sosialisasi kegiatan, perencanaan, pelaksanaan, dan evaluasi. Luaran dari kegiatan pengabdian masyarakat sudah memenuhi indikator capaian, yaitu seluruh pengajar $(100 \%)$ sudah memiliki akun email dengan domain (sch.id) yang dimiliki sekolah. Hasil penilaian dari mitra, $74 \%$ menyatakan kegiatan pengabdian masyarakat memuaskan.
\end{abstract}

DOI: https://doi.org/10.21107/pangabdhi.v7i2.10757

Kata Kunci : media pembelajaran, pembelajaran daring

\begin{abstract}
The world of education underwent major changes in 2020 due to the Covid-19 pandemic. The most visible impact of changes in the world of education in the midst of the Covid-19 pandemic is the effectiveness of the teaching and learning process that has turned online. One of the elementary schools that experienced these changes was SD N 9 Dauh Puri, North Denpasar. Online learning is currently being carried out at SD N 9 Dauh puri using WhatsApp and Google classroom media. However, in practice, teachers still use personal accounts in the use of online learning media, so the features of these learning media cannot be utilized optimally. In addition, the teachers also do not understand optimally in the use of these learning media. Based on these problems, through this service activity, assistance is provided in creating an account with a free domain provided by the government (.sch) as well as the school website. Other activities include training on the use of Google Forms as a medium for collecting assignments and evaluating learning. The implementation method of service activities consists of socializing activities, planning, implementing, and evaluating. The outputs of community service activities have met the achievement indicators, namely all teachers (100\%) already have an email account with a domain (sch.id) owned by the school and the school already has a website installed on the http://www.sdn9dauhpuri.sch page. id/. The results of the assessment from partners, $74 \%$ stated that community service activities were satisfactory.
\end{abstract}

Key Words : learning media, online learning

\section{PENDAHULUAN}

Dunia Pendidikan mengalami perubahan yang besar pada Tahun 2020 dikarenakan adanya pandemi Covid-19. Dampak yang paling terlihat atas perubahan dunia pendidikan di tengah pandemi Covid-19 adalah keefektifan proses belajar-mengajar yang berubah menjadi daring. Tidak semua peserta didik mampu beradaptasi dengan metode pendidikan yang baru ini, terlebih pada jenjang sekolah dasar (SD). Bukan hanya dari sisi peserta didik, tetapi juga dari sisi pengajar. Salah satu SD yang mengalami 
perubahan tersebut adalah SDN 9 Dauh Puri, Denpasar Utara. Sekolah ini berlokasi di Jalan Ahmad Yani II, Denpasar Utara. Seluruh peserta didik sudah menjalankan pembelajaran secara daring dari Bulan Maret 2020 hingga saat ini, namun para guru tetap ke sekolah dengan sistem shift. Gambar 1 menunjukkan tampilan sekolah dari bagian depan.

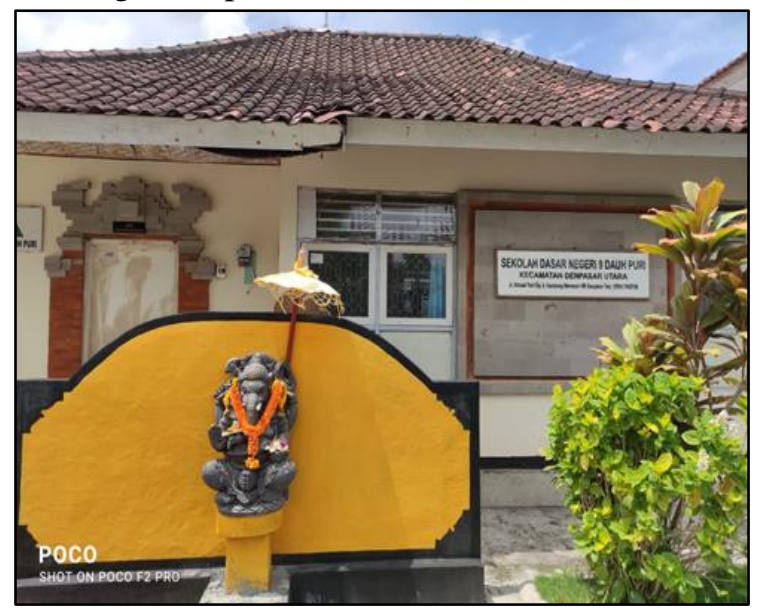

Gambar 1. Bagian Depan SD N 9 Dauh Puri

Para guru di SDN 9 Dauh Puri berjumlah 17 orang dengan total murid dari kelas 1 sampai 6 adalah 358 siswa Tiap kelas rata-rata berisi 30 sampai 40 siswa. Pembelajaran secara daring yang sedang dilaksanakan saat ini sudah menggunakan beberapa media daring, seperti Whatsapp, Google Classroom dan Google Form. Pemberian materi dilakukan dalam bentuk video dan disebarkan ke siswa melalui Whatsapp, sedangkan pemberian tugas dilakukan melalui Google Classroom maupun Google Form. Seluruh guru sudah terbiasa menggunakan media Whatsapp, namun hanya sekitar 8 guru (47\%) yang terbiasa menggunakan Google Classroom dan Google Form, sehingga variasi pembelajaran di beberapa kelas menjadi terbatas. Contoh tampilan pemanfaatan media tersebut, dapat dilihat pada Gambar 2. Namun, dalam penggunaan beberapa media tersebut, masih menggunakan akun pribadi. Hal ini dikarenakan sekolah belum memiliki akun resmi sekolah. Akun resmi tersebut akan sangat membantu sekolah dalam urusan administrasi, seperti pendaftaran akun G-Suite dari program Kemendikbud, sehingga tiap guru akan memiliki akun resmi sekolah (Rizkinaswara, 2019) (Ritonga et al., 2020).

Berdasarkan permasalahan yang telah dijabarkan sebelumnya, maka melalui kegiatan pengabdian ini akan dilakukan pendampingan dalam pembuatan akun dengan domain gratis yang disediakan pemerintah (.sch) sekaligus website sekolah dan pemanfaatan media pembelajaran daring menggunakan Google Form. Tujuan dari kegiatan pengabdian ini adalah melakukan diseminasi teknologi ke dalam kegiatan pembelajaran guna mendukung pembelajaran daring di masa pandemi.

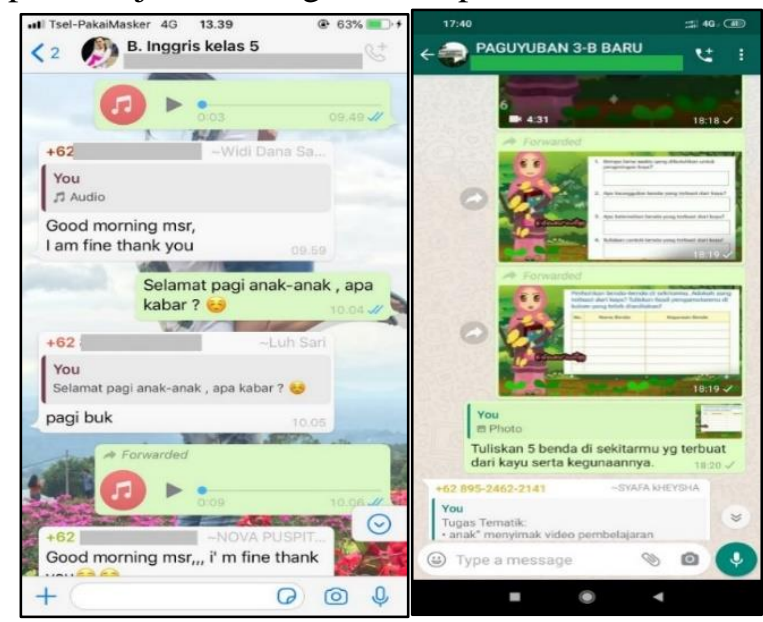

Gambar 2. Pelaksanaan Belajar Daring di SDN 9 Dauh Puri

\section{METODE}

Pendekatan yang ditawarkan bagi program pengabdian masyarakat pelatihan dan penyuluhan ini adalah metode diskusi, ceramah, dan praktek langsung. Langkah-langkah kegiatan pengabdian terdiri dari:

\section{1) Persiapan Kegiatan}

Langkah awal yang dilaksanakan sebelum memulai kegiatan pengabdian masyarakat adalah melakukan sosialisasi mengenai rencana kegiatan yang akan dilaksanakan di SD N 9 Dauh Puri.

\section{2) Pelaksanaan Kegiatan}

a) Pendampingan pembuatan akun resmi sekolah pada domain gratis (.sch), yaitu pembuatan website sekolah dan pengisian profil sekolah pada website (Akbar \& Tjendrowaseno, 2015).

b) Pelatihan pemanfaatan media pembelajaran daring menggunakan Google Form, berupa proses pengumpulan tugas sekolah dan pembuatan evaluasi pembelajaran.

\section{3) Monitoring dan Evaluasi}

Setelah kegiatan Program Kemitraan Masyarakat selesai dilaksanakan, maka evaluasi pelaksanaan program akan dilihat melalui pengisian kuesioner, dengan mitra sebagai responden. Hasil pengisian kuesioner akan dirangkum dan diolah menggunakan teknik pengolahan data dengan rumus rata-rata dan disajikan dalam bentuk grafik. 


\section{HASIL DAN PEMBAHASAN}

Pertemuan awal diadakan di sekolah SDN 9 Dauh Puri. Pertemuan tersebut diterima langsung oleh kepala sekolah SDN 9 Dauh Puri, didampingi salah satu perwakilan guru dan staf Tata Usaha yang khusus menangani bidang IT. Dokumentasi pertemuan dapat dilihat pada Gambar 3.

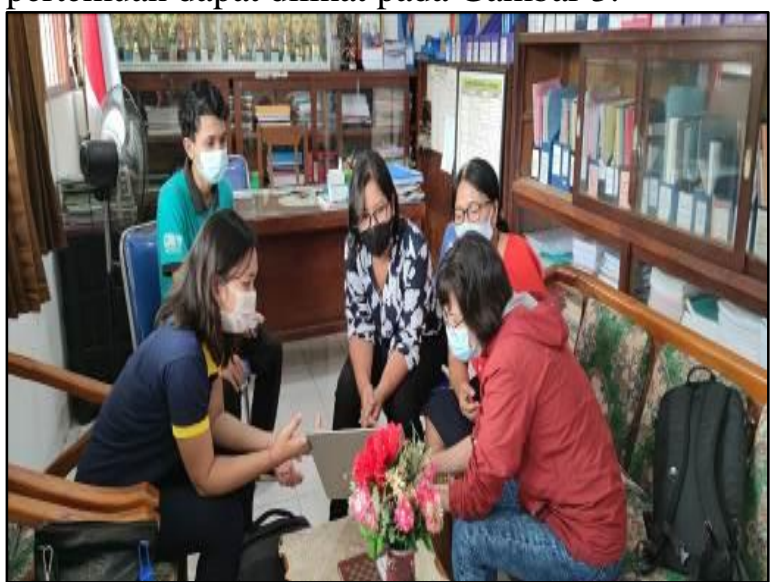

Gambar 3. Sosialisasi Kegiatan Pengabdian

$$
\text { Masyarakat }
$$

Pelaksanaan pengabdian dibagi menjadi dua kegiatan, yaitu pendampingan pembuatan website dan pelatihan pemanfaatan media pembelajaran daring. Setelah pelaksanaan kegiatan pengabdian, dilanjutkan dengan evaluasi kegiatan.

\section{Kegiatan Pendampingan Pembuatan Akun Resmi Sekolah dan Website}

Pendaftaran akun resmi sekolah (.sch.id) membutuhkan beberapa persyaratan, yaitu:

a. SK Pendirian Lembaga dari Kementerian atau SKPD terkait.

b. Surat Permohonan dari Kepala Sekolah/Pimpinan Lembaga.

c. KTP Kepala Sekolah/Pimpinan Lembaga.

Kegiatan dibagi menjadi beberapa tahapan, yaitu:

a. Pengembangan website sekolah; Website sekolah dikembangkan menggunakan Wordpress (Rochman et al., 2020; Devella et.al., 2021).

b. Pendaftaran domain (.sch.id) dan sewa hosting. Pendaftaran domain membutuhkan persyaratan khusus sesuai dengan yang telah dijabarkan pada tahap perencanaan. Hal ini dikarenakan, domain tersebut memang diperuntukkan untuk website resmi sekolah.

c. Pelatihan pengelolaan website kepada salah satu guru yang nantinya akan menjadi admin website sekolah. Pelatihan dilakukan secara daring melalui zoom.
Gambar 4 menunjukkan pelatihan yang dilaksanakan. Proses pengisian data pada website masih dilakukan secara bertahap selama tiga bulan ke depan. Hal ini dikarenakan, admin yang ditugaskan untuk melengkapi website sekolah tersebut hanya satu orang guru.
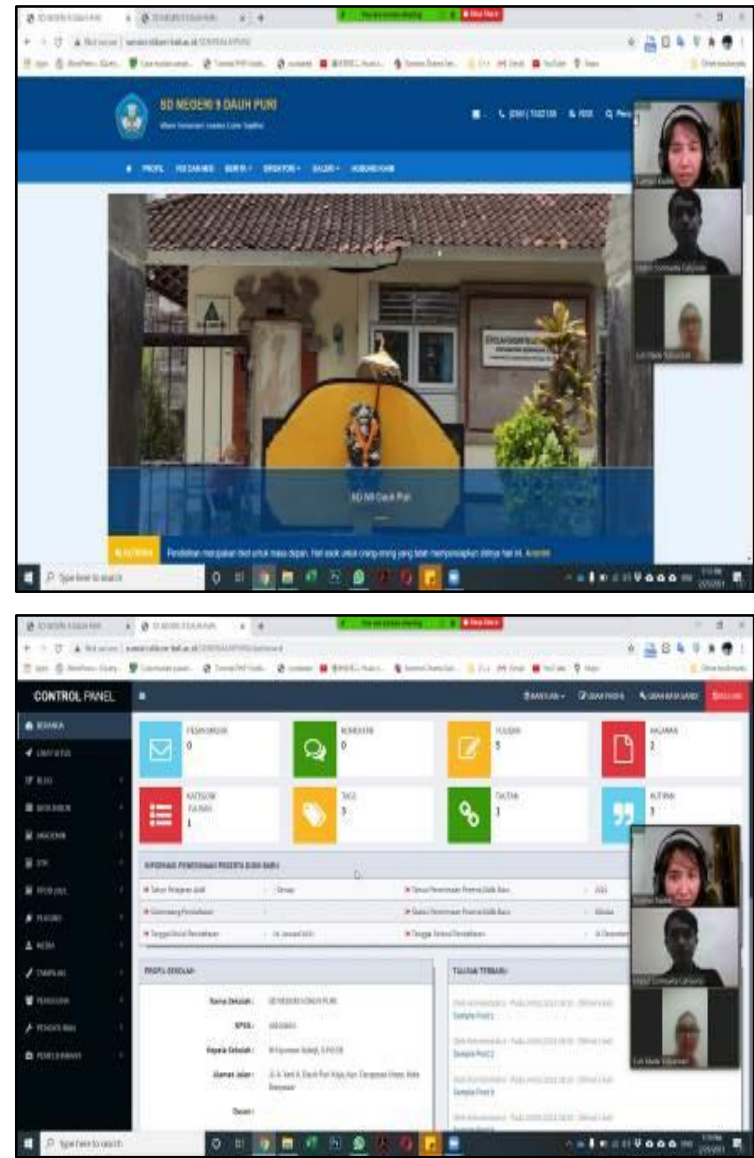

Gambar 4. Pelatihan Pengelolaan Website Sekolah

d. Proses unggah website ke hosting dan domain yang sudah didaftarkan. Website sekolah sudah dapat diakses melalui http://sdn9dauhpuri.sch.id/

e. Pembuatan akun email untuk seluruh guru dan staf sekolah, sesuai dengan daftar nama yang diberikan pihak sekolah.

\section{Kegiatan Pelatihan Pemanfaatan Media Pembelajaran Daring}

Pelaksanaan pelatihan dilakukan secara daring melalui aplikasi meeting online yaitu Zoom. Peserta pelatihan berjumlah 5 orang yang terdiri dari guru dan pegawai tata usaha. Hasil tangkapan layar pada saat pelaksanaan pelatihan dapat dilihat pada Gambar 5. Cakupan materi yang disampaikan terdiri dari:

a. Kendala pembelajaran daring 
b. Sumber belajar daring

c. Evaluasi belajar daring

d. Soal dengan deskripsi

e. Soal bercerita

f. Soal dengan batasan waktu

g. Soal dengan gambar, rumus, grafik, tabel

h. Membuat soal di Google Form

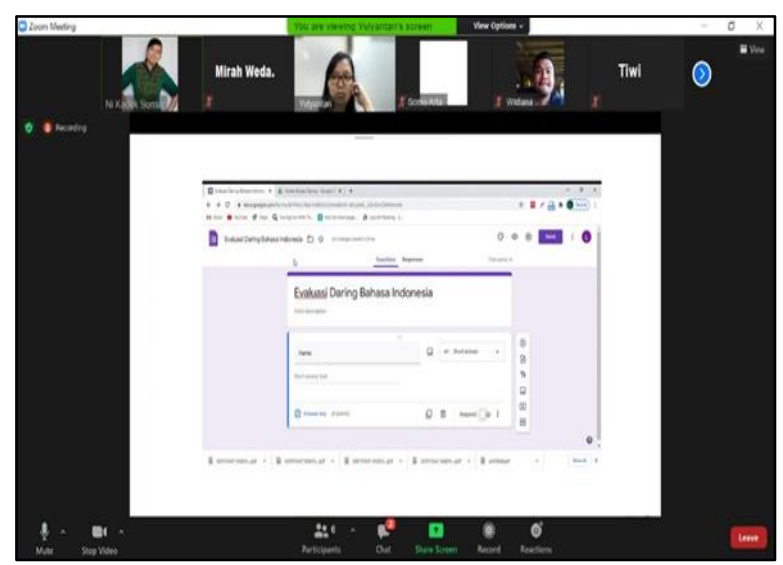

Gambar 5. Pelatihan Pemanfaatan Google Form

\section{Evaluasi Kegiatan}

Penilaian kegiatan dilakukan melalui kuesioner. Pertanyaan yang diajukan terkait pelaksanaan kegiatan dan performa pembicara. Berdasarkan hasil jawaban, secara keseluruhan hasil penilaian kegiatan dari mitra adalah $74 \%$ menyatakan kegiatan pengabdian masyarakat memuaskan. Grafik hasil monitoring dan evaluasi kegiatan dapat dilihat pada Gambar 6.

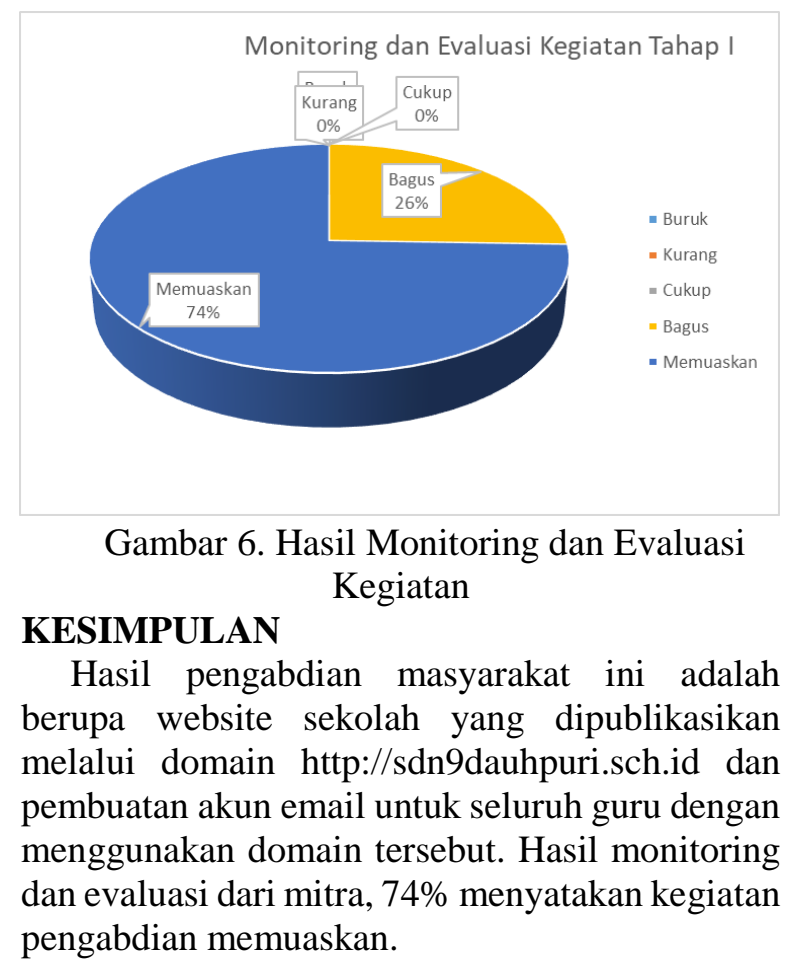

\section{DAFTAR PUSTAKA}

Akbar, G., \& Tjendrowaseno, T. I. (2015). Website Profil Sekolah Sebagai Media Informasi Dan Promosi. Indonesian Journal on Networking and Security, 4 (1).

Devella, S., Yohannes, Y., \& Rachmat, N. (2021). Pelatihan Pembuatan Website Sekolah Menggunakan Wordpress Untuk Guru Tik Sma Negeri 17 Palembang. Jurnal Pengabdian Masyarakat Berkemajuan, 4 (2), 406-411.

Indonesia, P. (2020). Surat Edaran Nomor 4 Tahun 2020 Tentang Pelaksanaan Kebijakan Pendidikan Dalam Masa Darurat Penyebaran Coronavirus Desease (Covid-19). Jakarta: Kementerian Pendidikan dan Kebudayaan Republik Indonesia.

Ritonga, M., Lahmi, A., Rimelfi, R., Bahri, F., \& Bagindo, I. T. (2020). Sosialisasi Pembuatan Soal Melalui Google Form Dalam Meningkatkan Kompetensi Guru Pai. Bernas Jurnal Pengabdian Kepada Masyarakat.

Rizkinaswara, L. (2019, 07 24). Pengelola Nama Domain Internet Indonesia. Diambil Kembali Dari Aptika Kominfo: Https://Aptika.Kominfo.Go.Id/2019/07/Penge lola-Nama-Domain-Internet-Indonesia/

Rochman, A., Hanafri, M. I., \& Wandira, A. (2020). Implementasi Website Profil Smk Kartini Sebagai Media Promosi Dan Informasi Berbasis Open Source. Ajcsr Stmik Bina Sarana Global, 2 (1).

Utari, R. (2013). Website Sebagai Media Humas Sekolah. Jurnal Penelitian Ilmu Pendidikan Universitas Negeri Yogyakarta, 6 (2). 